\title{
DOI: 10.52363/passa-2021.1-14
}

UDC: 351.72

Tohobytska V.D., doctoral student of Training Research and Production Center of the National university of civil defence of Ukraine.

\section{PERSPECTIVES OF DEVELOPMENT OF THE ORGANIZATIONAL AND LEGAL MECHANISMS OF PUBLIC MANAGEMENT IN SOCIO- ECONOMIC SPHERE AND DIGITALIZATION}

The article provides a comprehensive scientific substantiation and study of organizational and legal principles and mechanisms of public management of socioeconomic risks in the context of digitalization.

Emphasis placed on the fact that in complex modern state and social processes, as well as relations in the field of economic and entrepreneurial activities, it is difficult to imagine their functioning without the use of information and digital technologies, because their use has facilitated and even changed various areas of business and respectively management processes in the field of business administration. To date, in the scientific literature there are studies on such a phenomenon as digitalization, which are mainly descriptive in nature and relate to various areas of modern society, including the consequences of digitalization for modern society, directly at the enterprise level, the impact on enterprises of various fields. As well as the issue of digitalization of various sectors of the economy. Instead, the concept of "digitalization" and its place in the processes of business administration of business structures and socio-economic relations is becoming increasingly important.

It concluded that the management and business administration of the business structure in the digitalization of society should have a number of specific features, in particular, the entrepreneur should, taking into account modern technologies, become a story customer-oriented to the business structure. At the same time, customer orientation in the traditional economy and digital economy is of different nature: in 
the traditional economy, managing customer needs in the company as a whole, and in the digitalization of the economy - the needs of a particular consumer; as channels of advancement in the traditional economy are mainly offline communications, and in the digital economy - digitalization elements of public administration. The transition to customer orientation in a digital economy is an important management process that requires changes not only in individual business processes of business structures, but also in the work of the whole organization, certain adjustments must be made to the business administration of the business structure in general.

Keywords: public administration, socio-economic risks, digitalization, mechanisms of public administration, digital transformation.

Formulation of the problem. In complex modern state and social processes, as well as relations in the field of economic and entrepreneurial activities, it is difficult to imagine their functioning without the use of information and digital technologies, because their use has facilitated and even changed various areas of business and management processes in business. -administration. Today in the scientific literature there are studies on such a phenomenon as digitalization, which are mainly descriptive in nature and relate to various areas of modern society, including the consequences of digitalization for modern society, directly at the enterprise level, the impact on enterprises of various fields. , as well as the issue of digitalization of various sectors of the economy. Instead, the concept of "digitalization" and its place in the processes of business administration of business structures and socio-economic relations is becoming increasingly important.

Analysis of recent research and publications. In the scientific environment, theoretical and applied principles and aspects of the subject often attracted the attention of domestic and foreign scholars in various fields, including administrators, lawyers, philosophers, managers, who were sent to study the institutions of e-democracy and egovernment by authors such as I. Aristov, V. Babayev, V. Dreshpak, O. Orlov, V. Birkovich, V. Dreshpak, N. Hrytsyak, O. Kabanets, O. Karpenko, P. Klimushin, V. Kuybida, I. Lopushinsky, V. Deputy, A. Semenchenko, S. Solovyov, S. Chukut and 
others. At the same time, these scientists, as a rule, considered the field of public administration and the impact on its nature and specifics of digitalization in general, but the issue of determining the organizational and legal framework and mechanisms of public management of socio-economic risks in digitalization has not yet received proper theoretical and applied justification. and research.

Consequently, the purpose of this article is a scientific justification and study of organizational and legal principles and mechanisms of public management of socioeconomic risks in the context of digitalization.

Presenting main material. Digital transformation in public administration is considered as one of the conditions for maintaining Ukraine's competitiveness in the world economy. Today there is a significant growth of digital technologies, which inevitably affects the need for integration and transformational changes in the processes of business administration of business structures. The active use of digital technologies, mobile devices and much more leads to the need for global modifications of certain processes and management methods in various vectors of business structures. The need for the introduction of digital technologies in business, as well as the definition of organizational and legal principles and mechanisms of public management of socio-economic risks in the context of digitalization is indicated in various legal aspects [1, p. 200].

A comparative analysis of the dynamics of digitalization of the economy in Ukraine and foreign countries speaks of the need to transform the system of business administration of business structures in the context of digitalization of society. In developed countries, the share of the digital economy in their GDP is $5.5 \%$, in developing countries $4.9 \%$, but according to analytical data, in Ukraine this figure is $2.8 \%$ [2, p. 112-113].

The program of digital economy development pays serious attention to the development of high technologies and digital platforms, and accordingly, the growing need for technological innovations requires not only new staff competencies, but also the ability to generate and implement these innovations, which requires a qualitatively new concepts in the field of organizational inertia and 
changing approaches to business administration of business structures [3, p. 40].

The issues of digitalization in the global and digital transformation concern a significant number of projections and events in the relevant business structures. Changes in technology entail changes in the business processes of business structures, as well as in the field of public administration relations, affecting: staff; finances; marketing; logistics; production process and large other business processes of the business structure [4, p. 19].

In the conditions of fast-growing information technologies business structures are compelled to embody modern technologies in the activity. In addition, there is a need to implement business structures of blockchains, shell computing, neural networks and many other technologies. All this leads to the need for highly qualified staff. In some types of entrepreneurial activity, technologically highly trained personnel play a special role in digital business, which directly and indirectly affects the principles of public administration.

In turn, it should be noted that the digital service has a number of features, in particular: the method of service in the case of digital services remote; the service is available at any time; remote access; digital service delivery environment; absolute confidentiality of service provision; lower operating delays; great flexibility of consumption of the sector.

The transformation of the business administration system in the conditions of active development of the digital economy also affects the production process, in the case of doing business in the field of production [5]. There is a growing need for a radical change in the process of production management in connection with the growing dependence of production on the use of digital technologies. The introduction of digital technologies in the production process gives production and business structures a number of advantages: there is an increase in production flexibility, dynamic development of the main characteristics of the production process. Due to the growth of management efficiency it is possible to have higher competitive advantages, which in turn may have the effect of increasing the efficiency of each management structure [6, p. 59]. 
When digitally translating various administrative, economic, social processes, the state, companies and individuals are actively accumulating personal data, which in the digital society is becoming a significant asset of high value. It can be stated that the personal data market is already a reality. However, the state does not yet have effective tools to control and regulate this market. The state is also interested in collecting personal data as a basis for creating an effective management system, while having an unlimited amount of legal opportunities. However, any information systems, including those created on the site of government agencies, are unfortunately vulnerable to unauthorized interference. All this creates a situation of potential threat of violation of citizens' rights [7, p. 184].

Another important issue that digitalization entails is the status of the state itself, its role in the management of social processes, in the implementation of a number of constitutional and legal principles, and especially clearly these changes can be traced in the social sphere. We believe that the state will have to look for a new point of balance in the implementation of the principle of the welfare state. This is due to the impact of digitalization of the economy on society, because it is at the present stage of Ukrainian state formation that society most painfully and acutely perceives excessive social stratification. At the same time, according to most scientists, the problem of social stratification is only exacerbated, which is associated with the automation of production, which will lead to a radical reduction of jobs $\square$ millions of people may lose their jobs, and with it тільки not only material well-being but also lose a number social guarantees.

Digitalization already affects the most important state and legal institutions related to the formation of public authorities and the implementation of public authority. In connection with digitalization, conditions are created that can affect the type of modern representative democracy, at least the appearance of a number of existing state institutions may change. Steps in this direction are made by the state itself, which can be clearly seen in the implementation of certain aspects of public administration programs in the field of digital economy [8, p. 9].

Therefore, the introduction of such innovations can qualitatively affect not only 
certain sources of public administration, but the use of appropriate technologies simplifies and minimizes the procedure for expressing public opinion and the voting procedure. This means that a certain relationship between the forms of representative and direct democracy may require a certain transformation. The demand of society to improve the forms of citizen participation in the exercise of public power, including through the use of information technology, is very noticeable, to which the domestic state is trying to respond. As one of the examples of application of similar technologies in public administration it is possible to result initiative budgeting, ie distribution of a certain share of the budget on the basis of offers of inhabitants $[9, \mathrm{p}$. 44]. And there are ideas to implement proactive budgeting, including through the mechanism of online voting using an identification system. It should be noted that the presented approach deserves support, as it is aimed at expanding the rights of citizens to participate in the management of state affairs.

The implementation of such technologies will require the formation of a special environment of trust in the authorities as a whole and in the digital space formed by them. Despite serious technical advances, the introduction of this technology has serious risks associated, on the one hand, with the legitimacy of the results of online voting, and on the other hand - the psychological characteristics of citizen participation in this process.

Serious pressure of digitalization is felt in relation to the justice system, because modern digital technologies provide the opportunity to create a digital environment that can replace a system of individual bodies in the field of public authorities. Thus, the digitalization of state institutions and governance processes leads to the need to transform these institutions, as well as poses new challenges to society and the state, which can no longer be solved by proven and known methods. It should be noted that observing the process of transformation of the former system of world order, including in the social sphere, as its most important component, we can state that with the external preservation of all traditional institutions and mechanisms of its regulation, real relations are increasingly transformed. The achieved limit of social spending forces governments to look for effective solutions, and such a solution is 
the privatization of the social sphere. However, as soon as something falls into the sphere of market relations, it is subject to the laws of the market - reducing costs and maximizing profits. In fact, the market itself is a mechanism of free competition, where victory is "awarded" to those who were able to offer a cheaper mass product. The transfer of the entire social sphere to the market rails not only modifies reality, but radically transforms it, turning it into its opposite and, at the same time, complicating its analysis. Thus, the promotion of new, especially digital technologies that have the potential to solve problems in this area, is often due to purely financial logic, the task of maximizing profits, rather than interest in making the process of acquiring knowledge more interesting, effective, accessible, aimed at revealing unique abilities, etc. It must be understood that this is not a matter of someone's conscious choice, it is a tough aspect of competition. And examples of how some states, which tried, for example, to reduce the cost of medicines for their citizens, lost in court to multinational companies, are quite illustrative, but the same happens in the social and labor sphere $\square$ enterprises existing in the classical industrial paradigm of production, deliberately unable to compete with platform services in social spending and will be forced, one way or another, to adapt, becoming a platform, or go bankrupt. However, as a result, the aggregate effective demand is reduced, which should contribute to economic growth and create jobs [10, p. 140].

States' ability to finance social spending is further reduced. An alarming trend of our time, as we have already noted, is the growth of inequality. And such quantitative inequality (income inequality) is increasingly becoming a qualitative indicator - inequality in access to work, social policy, education and health care, for which "public needs" have become (at least at the regulatory level). public good ", which are rapidly becoming" services ". And the process is a clear illustration of how in parallel with the changing realities of life is the transformation of the basic sociopolitical and scientific concepts of the previous era.

Conclusions. Thus, we can conclude that the management and business administration of the business structure in the digitalization of society should have a number of specific features, in particular, the entrepreneur must, taking into account 
modern technology, become a story customer-oriented to the business structure. Thus customer orientation at traditional economy and digital economy has various character: in traditional economy of management of needs of clients in the company as a whole, and at digitalization of economy - inquiries of the concrete consumer; as channels of advancement in the traditional economy are mainly offline communications, and in the digital economy - digitalization elements of public administration. The transition to customer orientation in a digital economy is an important management process that requires changes not only in individual business processes of business structures, but also in the work of the whole organization, ie certain adjustments must be made to the business administration of the business structure in general.

\section{References}

1. Aver'yanov, V.B. (1999). Derzhavne upravlinnya v Ukrayni [Government ruled in the Ukraine]. Vidavnitztvo TOV "SOMI", Kyiv, Ukraine [in Ukranian].

2. Bakumenko, V. D. (2003). Theoretical and organizational principles of public administration [Teoretichni ta organizacijni zasadi derzhavnogo upravlinnya]. Kyiv, Ukraine [in Ukranian].

3. Bandurka, O. M. (2000). State regulation of the economy [Derzhavne regulyuvannya ekonomiku]. Harkiv, Ukraine [in Ukranian].

4. Belikova, T. Y. and Mishchenko, S. G. (2012). Management of strategic development of viable economic systems: models, mechanisms and tools: monograph [Upravlenie strategicheskim razvitiem zhiznesposobnyh ekonomicheskih sistem: modeli, mekhanizmy i instrumenty : monografiya]. Kiev, Ukraine [in Ukranian].

5. Byrkovych T. I., Byrkovych V. I., Kabanets O. S. (2019). "Mekhanizmy publichnoho upravlinnya u sferi tsyfrovykh transformatsiy" ["Mechanisms of public control in the field of digital transformations"]. Derzhavne upravlinnya: udoskonalennya ta rozvytok [Public Administration: Improvement and Development], vol. 9. URL: http://www.dy.nayka.com.ua/?op=1\&z=1488. DOI: 10.32702/23072156-2019.9.2 [in Ukrainian]. 
6. Grabar, N. S. and Khmyrov, I. M "Formation and transformation of mechanisms of public administration (on the example of management of intellectual and innovative resources of the economy in Ukraine) [Stanovlennya ta transformaciya mekhanizmiv derzhavnogo upravlinnya (na prikladi upravlinnya intelektual\&apos;noinnovacijnimi resursami ekonomiki v Ukrayni)]". Bulletin of NUTSZU. Public Administration Series. (1 (14). (2021): 58-65.

7. Kovalchuk, K. F. (2012). Innovation and investment policy of sustainable development of the regions of Ukraine: from theory to practice [Innovacijnoinvesticijna politika stalogo rozvitku regioniv Ukrayni: vid teoriy do praktiki]. Donetsk, Ukraine. [in Ukrainian].

8. Kuybida V.S., Karpenko O.V., Namestnik V.V. (2018), "Tsyfrove vryaduvannya v Ukrayini: bazovi definitsiyi ponyatiyno-katehorial'nohoaparatu", ["Digital Governance in Ukraine: Basic Definitions of the Conceptual and Categorical Apparatus"], journal Visnyk Natsionalnoyi akademiyi derzhavnoho upravlinnya pry Prezydentovi Ukrayiny. Seriya : Derzhavne upravlinnya [Bulletin of the National Academy of Public Administration under the President of Ukraine. Series: Public Administration], vol. 1, pp. 5-10. URL: http://nbuv.gov.ua/UJRN/vnaddy_2018_1_3 [in Ukrainian].

9. Lakhyzha, M.I. (2012). Modernizatsiia publichnoi administratsii: dosvid Respubliky Polshcha.Poltava: PoltNTU[in Ukrainian]

10. Orekhova, T. V. Theoretical and applied problems of modeling sustainable development of economic systems: a monograph [Teoretichni i prikladni problemi modelyuvannya stalogo rozvitku ekonomichnih sistem : monografiya]. Donetsk, 2013. Print. 